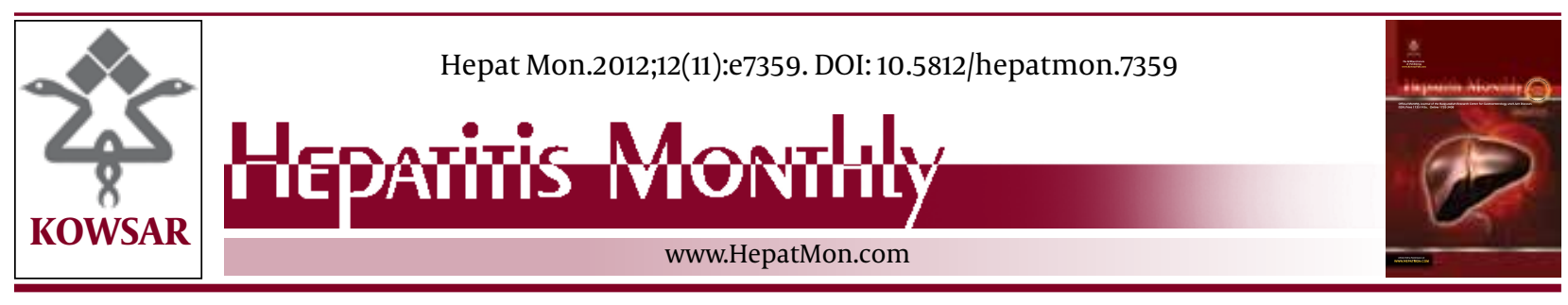

\title{
Hepatitis B Vaccination in Chronic Kidney Disease: Review of Evidence in Non-Dialyzed Patients
}

\author{
Alicja E. Grzegorzewska ${ }^{1^{*}}$ \\ ${ }^{1}$ Department of Nephrology, Transplantology and Internal Diseases, Poznań University of Medical Sciences, Poznań, Poland
}

\begin{tabular}{l}
\hline A R T I C L E I N F O \\
\hline Article type: \\
Review Article \\
\hline Article history: \\
Received: 21 Jul 2012 \\
Revised: 29 Aug 2012 \\
Accepted: 2 Sep 2012 \\
\hline
\end{tabular}

\section{Keywords:}

Vaccination

Hepatitis B Virus

Kidney Disease

\begin{abstract}
A B S T R A C T
Context: Hepatitis B vaccination of hemodialysis patients is performed all over the world. There are also recommendations from world health organizations to vaccinate patients with chronic kidney disease (CKD) prior dialysis commencement, but the implementation of a hepatitis B vaccination program is less common and not well organized. Evidence Acquisition: This review article summarizes data indicating why, when and how to vaccinate CKD patients before they start renal replacement therapy. Publication for this review was bringing into being from PubMed.

Results: There is an agreement in the nephrological societies and among clinicians and scientists that CKD patients should be vaccinated in early stages of their disease, because a higher glomerular filtration rate is more likely to be associated with the responsiveness to vaccination. Schedules of vaccination and optimal vaccine doses are still being investigated. Differences in data with respect to these problems may result from comparisons of various vaccine doses and vaccination schedules without reference to one gold standard, variations in patients ` clinical status and glomerular filtration rate, and also the small groups of the affected patients make statistical analysis non-conclusive. A titer of antibodies to surface antigen of hepatitis B virus (anti-HBs) $>10 \mathrm{IU} / \mathrm{L}$ or $\geq 10 \mathrm{IU} / \mathrm{L}$ is commonly considered as a marker of seroconversion to anti-HBs positivity after vaccination in both non-dialyzed and dialyzed patients. In advanced CKD, vaccine-induced serconversion rate is seldom observed in more than $90 \%$ of vaccinees. Various strategies have been utilized in order to increase vaccine-induced seroconversion rate in patients with advanced CKD. Changing the injection mode, the use of adjuvants and immunostimulants to improve the immunogenicity of existing recombinant hepatitis B vaccines, introduction of mammalian-cell derived pre-S/S HBV vaccines (third-generation vaccines) were tried in order to improve the immunization rate.

Conclusions: There are a substantial number of non-responders to the hepatitis B vaccine among CKD patients. Therefore, successful prevention of hepatitis B virus transmission and spread will only be attained when hepatitis B vaccination is applied together with full implementation of appropriate infection control procedures.
\end{abstract}

Published by Kowsar Corp, 2012. cc 3.0.

Implication for health policy/practice/research/medical education:

About $20 \%$ of dialysis patients do not develop a protective titer of antibodies to hepatitis B virus surface antigen. Therefore, hepatitis B vaccination is suggested for patients with chronic kidney disease prior dialysis commencement, when the immune system is less compromised. This article presents methods and efficacy of hepatitis B vaccination in non-dialyzed patients with chronic kidney disease. It provides current knowledge on this subject, and also indicates problems which are not fully explained and need to be further investigated.

\footnotetext{
${ }^{*}$ Corresponding author: Alicja E. Grzegorzewska, Department of Nephrology, Transplantology and Internal Diseases, Poznań University of Medical Sciences, 49 Przybyszewskiego Blvd, 60-355 Poznań, Poland. Tel:+48-618691700, Fax:+48-618691688,E-mail:alicja_grzegorzewska@yahoo.com

DOI: 10.5812/hepatmon.7359

Copyright@ 2012 Kowsar Corp. All rights reserved.

This is an Open Access article distributed under the terms of the Creative Commons Attribution License (http://creativecommons.org/licenses/by/3.0), which permits unrestricted use, distribution, and reproduction in any medium, provided the original work is properly cited.
} 
- Please cite this paper as:

Grzegorzewska AE. Hepatitis B Vaccination in Chronic Kidney Disease: Review of Evidence in Non-Dialyzed Patients. Hepat Mon. 2012; 12(11):e7359. DOI: 10.5812/hepatmon.7359

\section{Context}

Prevention of infectious diseases is an important problem worldwide. Hepatitis B may be largely preventable by vaccination. Administration of hepatitis $B$ virus (HBV) surface antigen (HBsAg) in recombinant vaccines leads to the development of protective antibodies to HBV (anti-HBs) in responders. Lack of the development of anti-HBs means vaccinees is susceptible to HBV infection. Special population groups, among them patients with chronic kidney disease (CKD) requiring renal replacement therapy (RRT), essentially hemodialysis (HD), are already recognized as a risk group. Strict procedures controlling transmission of blood-born infections during HD sessions as well as hepatitis B vaccination are recommended and are introduced on mandatory basis in most HD centers worldwide. The Center for Disease Control and Prevention in Atlanta (USA) has recommended hepatitis B vaccination of HD patients since 1982 (1). In the United Kingdom (UK), vaccination of HD patients likely to have dialysis abroad was also recommended in 1982 by the Advisory Group in Hepatitis (2). However, in the UK in 1987-1991, most (63.8\%) of the analyzed dialysis units routinely immunized staff but only $5 \%$ routinely immunized patients (3). Among HD patients susceptible to $\mathrm{HBV}$, the two-year risk of seroconversion for $\mathrm{HBV}$ infection was $38.9 \%$, accounting for 19 seroconversions to HBsAg positivity per 100 patient-years (4). In 1999 it was reported from the USA that the risk for HBV infection was $70 \%$ lower in vaccinated HD patients compared to those who did not receive the vaccine (5). During 1997-2002, the percentage of patients vaccinated against HBV infection in the USA increased from $47 \%$ to $56 \%$ (6). The prevalence of HBV infection in USA HD patients, defined as the percentage of all HD patients who tested positive for HBsAg, progressively fell from $7.8 \%$ to $1.0 \%$ between 1976 and 2002 (6). In the last two decades, the incidence of HBV infection during HD treatment, defined as the percentage of all patients receiving HD during the data collection period who seroconverted from HBsAg negative to HBsAg positive, decreased remarkably worldwide mainly due to implementation of hepatitis $B$ vaccination in the majority of HD patients. Recent data indicate that HBsAg positivity de novo accounts for about 0.15 episodes per 100 patient-years (7-9). However, the true infection rate should also include incidence of positivity to antibodies to HBV core antigen (anti-HBc). Such an incidence was evaluated as 2.35 episodes/100 patient-years (7). Results of hepatitis $B$ vaccination in patients already requiring RRT are, however, not fully satisfactory, because patients with advanced CKD typically show an impaired immune response to hepatitis B vaccination compared to healthy individuals. Immune and non-immune low responsiveness to viral antigens shown in HD patients as compared with individuals without impaired renal function results in the former group in a lower frequency of anti-HBs development. Compared to a response rate of over $90 \%$ in the general population (10), only 50 to $85 \%$ of dialysis patients achieve antibody levels conferring protection [> $10 \mathrm{IU} / \mathrm{L}$ (11)] following hepatitis B vaccination (10, 12-18). Lower responsiveness to hepatitis B vaccination occurs despite recommendations to use higher vaccine doses in HD patients than in general population (19). Moreover, an anti- HBs titer tends to fall with time in persons who mounted an antibody response. In dialysis patients, the loss of hepatitis B immunity seems to be quicker than in healthy subjects $(10,16,18)$. Ineffective vaccination is predictive for prevalence and incidence of HBsAg positivity (4) and anti-HBc positivity $(7,20)$. At present, the attention of nephrologists is focused on CKD patients, who are currently non-dialyzed, but as their kidney disease progresses, it is likely to lead to RRT in the future. Hepatitis $B$ vaccination of such patients is thought to decrease a number of HBV susceptible patients on RRT. The purpose of this overview is to summarize data on hepatitis B vaccination in CKD patients not requiring RRT (dialysis or renal transplantation) and to show arguments answering the question as to why we should to vaccinate patients in early CKD stages.

\section{Evidence Acquisition}

Publications for this review, not the time duration of search limited, were found in PubMed in response to catchwords: "hepatitis B vaccination, pre-dialysis" ( 5 citations), "hepatitis B vaccination, chronic kidney disease" (196 citations), "hepatitis B vaccination, dialysis" (372 citations), and "hepatitis B vaccination, kidney transplantation" (76 citations). Articles, selected for citation in this review, were chosen on the basis of their originality and efficacy in discussion on advantages/disadvantages of hepatitis B vaccination in early CKD stages. Results of the literature review were organized in various parts concerning facts on factors involved in non-responsiveness to $H B V$ vaccination (1), results of hepatitis B vaccination in different CKD stages (2), prevention of HBV infection prior dialysis commencement (3), anti-HBs decline and a response to booster doses (4), methods of hepatitis B vaccination in non-dialyzed CKD patients (5), protective antiHBs titer (6) trials for improvement of vaccine-induced seroconversion rate (7), future options (9), and summary 
and conclusions (8).

\section{Results}

\subsection{Factors Involved in Non-responsiveness to HBV Vac-} cination

Numerous inherited and/or acquired factors are implicated in diminished immunization following hepatitis B vaccination. However, at first we should exclude variables such as improper storage or administration that is not compatible with a manufacturer instruction. Involvement of genetic factors in the anti-HBs development is continuously examined. Already in the 70-ties of the past century, immune response to HBsAg in HBV infected HD patients was linked to human leukocyte antigens (HLA) $(21,22)$. In 1985 Hashimoto et al. (23) linked HLA with antiHBs response to hepatitis B vaccine. In 1988 HLA-linked immune suppression gene controlling the non-responsiveness to HBsAg through HBsAg-specific suppressor $\mathrm{T}$ cells was found in Japanese population (24). In Caucasians, an association between the HLA-B8, DR3 haplotype and low responsiveness to HBsAg was noted (25), whereas an association between the HLA-DR1 and high responsiveness to HBsAg was described in both Caucasian (26) and Japanese persons (27). In 1990, HD patients, identified as non-responders, had shown to have a higher frequency of HLA-A1, B8 and DR3 than non-responders (15). In 1998 Hohler and et al. (28) have reported enhanced expression of DRB $1 \times 3$, DRB $1 \times 7$ and DRB $1 \times 14$ in nonresponders to hepatitis B vaccine. More recently, interleukin genotypes (examples IL10, IL-12, IL-18) were associated with the antiHBs development in response to HBsAg in HD patients (29-31). A very well established negative factor of immunization failure is increasing age (30, 32-34). Seroconversion rate to anti-HBs positivity after vaccination was $84 \%$ in HD patients below 40 years and only $33 \%$ in those $\geq 60$ years (34). The impaired response to hepatitis B vaccine in dialysis patients has been also attributed to male gender $(15,35)$, poor nutritional status, mainly low serum albumin concentration $(36,37)$, serological positivity for hepatitis C virus (HCV) (38) or human immunodeficiency virus (HIV) (39), and diabetes mellitus (29, 40). Vitamin $D$ deficiency was associated with a poor antibody formation upon hepatitis B vaccination in stage 3-5D CKD patients (41). It is well known that dialysis patients are immunocompromised. Severity of immune abnormalities increases with deterioration of renal function. The best example is correlation of serum soluble CD40 levels with creatinine in non-dialyzed CKD patients. Soluble CD40 is able to inhibit immunoglobulin production by CD154activated B lymphocytes in vitro. HD patients presented a fivefold increase in soluble CD40 compared to healthy subjects, whereas non-dialyzed CKD patients showed a three-fold increase. Furthermore, the positive correlation was observed between the serum levels of soluble CD40 and the deficient response to hepatitis $B$ vaccination
(42). These and other data showing deterioration of the immune system in the course of CKD should be a strong reason for vaccination of CKD patients in initial stages of their renal diseases. Increasing prevalence of immune abnormalities and co-morbidities with severity of CKD, which decreases vaccine-induced immunization, leads to the conclusion that hepatitis B vaccination before dialysis commencement may benefit in the better protection against $\mathrm{HBV}$ when patients start RRT.

\subsection{Results of Hepatitis B Vaccination in Different CKD Stages}

In 1988, Seaworth et al. (43) published that seroconversion rates in excess of $80 \%$ can be achieved if patients are given a vaccine prior the onset of dialysis dependence. When they analyzed results of currently available evidence, it was shown that patients with renal failure not yet dependent on dialysis respond more favorably to the plasma-derived vaccine than dialyzed patients (80 vs 50\%). In 1999, Agarwal et al. (44) demonstrated very convincingly that CKD patients should be vaccinated at the very early stage of CKD. They showed that seroconversion rate among patients with mild (creatinine 1.5 to $3.0 \mathrm{mg}$ $\%$ ), moderate (creatinine 3.0 to $6.0 \mathrm{mg} \%$ ) or severe (creatinine $>6.0 \mathrm{mg} \%$ ) CKD was $87.5 \%$, 66.6\%, and $35.7 \%$ after three $40 \mu \mathrm{g}$ vaccine doses, respectively, and $100 \%, 77 \%$, and $36.4 \%$, respectively, following four $40 \mu \mathrm{g}$ vaccine doses. In 2003, DaRosa et al. (45) have shown that CKD stage predicts seroconversion after hepatitis B immunization and also concluded that to vaccinate earlier would be beneficial. Authors prospectively analyzed 165 patients with median estimated glomerular filtration rate (GFR) of 20 (interquartile range, 14 to 20 ) $\mathrm{mL} / \mathrm{min}$. Seroconversion rate was $82 \%$. Level of GFR showed the independent positive predictive value for seroconversion in multivariate analyses.

In the study by Hashemi et al. (14) a higher estimated GFR was not associated with significantly improved seroconversion, but their data (not adjusted for significant differences in age, body mass, and hemoglobin between groups) also indicate statistically borderline decrease $(P=0.067)$ in positive response with deteriorating GFR: $80 \%$ in CKD stage 3, 76\% in CKD stage 4 and $67 \%$ in CKD stage 5. Moreover, data by Hashemi et al. (14) showed a significant positive correlation between an anti-HBs titer and estimated GFR. CKD stage, however, was not associated with seroconversion in the multivariate analysis. When seroconversion rate in CKD stage 5 is compared to that attained in CKD stage 5D, differences are usually not-significant. Bel'eed et al. (46) demonstrated that the vaccine-induced seroconversion rates were similar in predialysis patients with serum creatinine $>400 \mu \mathrm{mol} / \mathrm{L}$ (68\%), HD patients (66\%), and peritoneal dialysis patients (66\%). For comparison, serological response to hepatitis B vaccine in HIV-infected children was 59.5\% (47). Differ- 
ences in aforementioned data may result from various vaccine doses and vaccination schedules, variations in patients' clinical status and GFR, and likewise from small groups of the examined patients, makes statistical analysis non-conclusive. Experts' opinions, which based on currently available evidence and experience, resulted in recommendations of hepatitis B vaccination before dialysis commencement. In 1988 in the UK it was recommended that patients with chronic renal failure should receive hepatitis $B$ vaccine early in the course of their disease (48). Guidance from the UK Health Departments in 1991 suggested that CKD patients should "be immunized as soon as it becomes likely that they will ultimately require treatment by maintenance haemodialysis or renal transplant" (49). According to European Best Practice Guidelines (2002) "patients with progressive renal failure should be vaccinated against HBV preferably before the start on HD" (11). Although immunization rates not always seem to be much higher and stronger in non-dialysis patients $[67-100 \%(14,43-46,50,51)]$ than in those already dialyzed $[50-85 \%(10,12-18,46)]$, hepatitis B vaccination of CKD patients should be advocated in early stages of the kidney disease for other several reasons shown in the next parts of this review.

\subsection{Prevention of HBV Infection prior Dialysis Com- mencement}

CKD patients entering dialysis programs frequently demonstrate serological markers of HBV transmission. In our study HBV infection in $82 \%$ of HBsAg positive patients was not associated with HD treatment, for the reason that it was acquired before HD commencement (13). The total rate of HBV seromarkers was $20.9 \%$ in patients starting HD therapy in Lima hospital. HBsAg positive patients amounted for $2.3 \%$ of all new HD persons; such patients usually replicate HBV and may be a potential source of infection for other HD patients. Anti-HBc positivity with negative HBsAg (or decreased to an undetectable level) reached $18.7 \%$ in patients using the HD program for the first time (52). Although such patients are routinely considered as having HBV transmission in the past and not infectious to others, there is an increasing evidence that these persons may replicate HBV (occult HBV infection) or may start to replicate under special circumstances (immunosuppression, cachexia). Vaccination in early CKD stages may help to avoid HBV infection before the start of dialysis and to decrease a risk of HBV transmission in dialysis centers, where such a possibility is much higher than in noninvasive healthcare facilities.

\subsection{Anti-HBs Decline and a Response to Booster Doses}

A time-related anti-HBs decline is well known phenomenon. In the general population, hepatitis B vaccination provided strong protection against infection for at least
15 years in all age groups, although antibody levels decreased the most among individuals immunized at 4 years of age or younger (53). In children, loss of anti-HBs was observed in $18.4 \%$ after 5 years (54). In the general population, a greater anti-HBs decline in adult females than males was shown in the study by McMahon et al. (53). In dialyzed patients, loss of anti-HBs is more rapid than in the general population. A year since standard vaccination, $(3 \times 20 \mu \mathrm{g})$ of healthy persons $77.2-82.5 \%$ of vaccine recipients had an anti-HBs titer $>10 \mathrm{IU} / \mathrm{L}$, whereas HD patients having $4 \times 40 \mu \mathrm{g}$ vaccination schedule showed the positive titer in $53.3 \%$ of cases (10). In another study, $26 \%$ of HD patients lost immunity during $6-36$ months of observation (18). The waning of protective anti-HBs antibodies was detected in $47 \%$ and $68 \%$ of dialysis patients during 3 and 5 years following vaccination, respectively (16). A quicker decrease or loss of anti-HBs in dialysis patients compared to the healthy population may be related to the reduced anti-HBs levels immediately after vaccination and impaired immune status in the former group. Healthy immunocompetent individuals usually do not need monitoring of anti-HBs and booster doses when they were effectively immunized by the primary hepatitis B vaccination series (55), especially when their documented anti-HBs titer was $>100 \mathrm{IU} / \mathrm{L}$. In vaccinated HD patients, anti-HBs should be followed-up regularly to give a boosting dose of HBV vaccine whenever anti-HBs titer approaches $10 \mathrm{IU} / \mathrm{L}$. According to the European Best Practice Guidelines for HD patients, anti-HBs should be checked every 6-12 months (11). American Association for the Study of Liver Diseases recommends annual followup testing of hemodialyzed vaccine responders (56). Efficacy of a response to booster doses may be of importance for making decisions when to vaccinate CKD patients. Dukes et al. (57) have observed that progression to dialysis was associated with poorer initial response to vaccination compared with the response in patients remaining dialysis-independent, but the response to booster immunization was favorable in both groups. They concluded that immunization of predialysis patients and subsequent booster vaccine resulted in a more favorable antibody response than has been seen in HD patients. Preemptive renal transplantation has become increasingly popular. Candidates for such a method of RRT should be vaccinated against HBV in the pre-transplant period. Renal allograft recipients on immune suppressants, even vaccinated with an enhanced scheme $(4 \times 40 \mu \mathrm{g}$ of the recombinant vaccine), show low seroconversion rate [36\% in the study by Lefebure et al. (58)]. Patients with poor renal graft function (serum creatinine $>400 \mu \mathrm{mol} / \mathrm{L}$ ) had lower seroconversion rate than CKD patients with serum creatinine $>400 \mu \mathrm{mol} / \mathrm{L}$ ( $41 \% v s .68 \%$ ) (46). On the other hand, recipients vaccinated before transplantation developed anti-HBs in $86 \%$ of cases in response to a booster injection (58). 


\subsection{Methods of Hepatitis B Vaccination in Non-dialyzed CKD Patients}

There are detailed recommendations how to vaccinate general population and dialysis patients. Standard hepatitis B vaccination schedule, commonly used in the general adult population means three $20 \mu \mathrm{g}$ licensed conventional recombinant vaccine doses at zero, one and six months. HD patients should be vaccinated against HBV using licensed conventional recombinant HBV vaccines given at zero, one, two and six months in the dose of 40 $\mu \mathrm{g}$ each. A vaccine has to be administered by the intramuscular route at one site. Patients who did not respond to the primary vaccine series should be revaccinated with three additional doses and retested for response (1). Four doses of the recombinant vaccine (40 $\mu \mathrm{g}$ each) were given to HD patients prior establishment of these recommendations and are at present commonly used worldwide $(10,18)$. The deltoid muscle is the preferred injection site; gluteal injections have been associated with lower response rates, because a vaccine was probably injected to fat rather than muscle $(59,60)$. Various immunization strategies have been developed for hepatitis $B$ vaccination of non-dialyzed CKD patients, but none are commonly accepted. Available data reveals that in nondialysis CKD patients there is a need for trials evaluating modification of standard hepatitis B vaccination $(3 \times 20$ $\mu \mathrm{g}$ at zero, one and six months) towards increased doses, comparable to those used in dialysis patients. Agarwal et al. (44) compared two hepatitis B vaccination schedules in patients with mild (creatinine 1.5 to $3.0 \mathrm{mg} \%$ ), moderate (creatinine 3.0 to $6.0 \mathrm{mg} \%$ ), and severe (creatinine > $6.0 \mathrm{mg} \%)$ CKD. Doses of $40 \mu \mathrm{g}$ of recombinant vaccine Engerix (20 $\mu$ g in each deltoid region) were given at zero, one and two months (3-dose group) or at zero, one, two, and six months (4-dose group). In the 3-dose group, the seroconversion rate among patients with mild, moderate, and severe CKD was $87.5 \%, 66.6 \%$, and $35.7 \%$, respectively, whereas in the 4-dose group it was $100 \%, 77 \%$, and $36.4 \%$, respectively. They concluded that patients with CKD should be vaccinated using $40 \mu \mathrm{g}$ of vaccine, and that 4 doses is better than 3 doses (44). In the study by McNulty et al. (61), Engerix B recombinant vaccine doses of $40 \mu \mathrm{g}$ administered at 0,1 and 6 months to predialysis patients with moderate chronic renal failure attained equivalent seroconversion to 3 doses of $20 \mu \mathrm{g}$ (67\% vs. $57 \%, p=0.27$ ). However, this $10 \%$ difference is significant, if the same seroconversion rate is maintained in 5 times greater groups $(P=0.015$, the Fisher test). Ahmadi et al. (50) have found that in CKD patients 3 doses of $20 \mu \mathrm{g}$ did not indicate a significantly different seroconversion rate compared to 4 doses of $40 \mu \mathrm{g}$ ( $92 \% v s .80 .9 \%, P=0.41)$. On the other hand, in the same study, they have shown that the 4 -dose hepatitis B vaccine ( $40 \mu \mathrm{g}$ each) resulted in the significantly greater seroconversion than 3 doses of $40 \mu \mathrm{g}$ ( $80.9 \%$ vs. $77 \%, P=0.004$ ). This inconsistency may result from the small number of studied patients. In summary, a majority of the aforementioned results indicates directly or indirectly that higher doses of vaccine generate higher seroconversion rates.

\subsection{Protective Anti-HBs Titer}

Vaccinees that developed an anti-HBs titer above two and below $10 \mathrm{IU} / \mathrm{L}$ are sometimes referred to as hyporesponders. An anti-HBs titer of $>10 \mathrm{IU} / \mathrm{L}$ or $\geq 10 \mathrm{IU} / \mathrm{L}$ is commonly considered as a marker of positive seroconversion, but vaccinees that developed an anti-HBs titer between 10 and $100 \mathrm{IU} / \mathrm{L}$ are sometimes referred to as low responders. In the UK, the optimum response, conferring seroprotection against $\mathrm{HBV}$ infection, was defined at an anti-HBs titer $\geq 100 \mathrm{IU} / \mathrm{L}$ (62). An anti-HBs titer $>10 \mathrm{IU} / \mathrm{L}$ is also referred as a "protective" titer, although it may not confer protection after HBV transmission in every case. Renal transplant recipients underwent $\mathrm{HBV}$ infection from HBsAg positive renal allografts despite having anti-HBs acquired by vaccination (63). Occurrence of an anti-HBs titer $>10 \mathrm{IU} / \mathrm{L}$ in $67 \%$ of patients who seroconverted to anti-HBc positivity also suggests that such an anti-HBs titer does not always protect against HBV infection in HD patients (7). Lombardi et al. (64) postulated that in dialysis patients an anti- HBs titer $>50$ IU/L should be considered as protective. In some groups of patients, like HBsAg negative children awaiting liver transplantation, an anti-HBs titer $>200 \mathrm{IU} / \mathrm{L}$ was advised to be sufficient to prevent de novo HBV infection (65). Fabrizi et al. (66) have listed a few circumstances under which a level of $10 \mathrm{IU} / \mathrm{L}$ might not completely exclude HBV infection. These would include exposure to an overwhelming HBV dose (67), production of antibody recognizing an HBsAg determinant different from that common to all subtypes $(68,69)$, or infection by an HBV mutant producing HBsAg with determinants not neutralized by anti-HBs $(70,71)$.

\subsection{Trials for Improvement of Vaccine-induced Serocon- version Rate}

Various strategies have been utilized in the past to increase the vaccine-induced seroconversion rate in patients with advanced CKD. Changing the injection mode (the intradermal route $v s$. the intramuscular route or the combined use of the intradermal and intramuscular routes) was tried, also in predialysis patients (72-74), showing controversial results. Hepatitis B vaccination scheme involving the combined use of the intradermal and intramuscular routes, elaborated by Marangi et al. (73) in non-dialyzed and dialyzed patients with serum creatinine concentration $\geq 4 \mathrm{mg} / \mathrm{dL}$, yielded very promising effects (all patients developed anti-HBs); however, it did not become widely popular. In 1984, Milich et al. (75) showed that enhanced immunity to HBsAg can be induced using pre-S antigens in non-responder mice resistant to protein $S$ of HBsAg. Third-generation vaccines, which contain mammalian-cell derived pre $-S_{1} /$ pre $-S_{2}$ 
/ S have been developed. Pre-S antigens seem to induce neutralizing antibodies, which block attachment, endocytosis and possibly membrane penetration of HBV into the hepatocyte (76). Pre-S/S vaccines should provide faster and more augmented seroconversions rates compared to recombinant vaccines. The immunogenicity of thirdgeneration vaccine was demonstrated in 120 pre-dialysis patients who received 5-doses of either $20 \mu \mathrm{g} /$ dose of the pre - $S_{2} / S$ Gen Hevac $B \circledR$ vaccine or $5 \mu \mathrm{g} /$ dose of the Pasteur plasma-derived vaccine at zero, one, two, four and 12 months (51). The recombinant vaccine elicited the higher seroconversion rate (anti-HBs titer $\geq 2 \mathrm{IU} / \mathrm{L}$ ) as compared to the plasma-derived vaccine ( $94 v s .76 \%$ ), but difference in seroconversion to anti- HBs titer $\geq 10 \mathrm{IU} / \mathrm{L}$ was borderline ( $84 v s .70 \%, p=0.053$ ). The use of adjuvants to recover the immunogenicity of existing recombinant HBV vaccines is suggested from results of experimental studies. Hepatitis B recombinant DNA vaccine adjuvanted by AS04C containing 3-0-desacyl-4'-monophosphoryl lipid A adsorbed on aluminium phosphate (Fendrix) was reported be more effective in HD patients than the older recombinant vaccine (Engerix) (77). Three doses of the investigational ASO2 (v)-adjuvanted hepatitis B vaccine HB-ASO2 have been shown to induce still more rapid seroprotection and higher anti-HBs antibody concentrations in CKD patients than four doses of Fendrix (78). This vaccine was also reactogenic in $76.9 \%$ of CKD patients who failed to respond to prior vaccination with a conventional hepatitis B vaccine and provided higher anti-HBs concentrations following a booster dose than a conven- tional vaccine (79). However, Fabrizi et al. (80) showed in their meta-analysis of prospective randomized trials that the immune response to recombinant hepatitis $B$ vaccine continues to be unsatisfactory despite adjuvantation. Coadministering levamisole p.o. (17), the use of polymethylmethacrylate dialyzers able to remove serum high molecular weight toxins, among them soluble CD40 (81), supplementation with zinc aspartate after each dialysis session (82), the use of thymopentin s.c. (83), granulocyte macrophage colony stimulating factor (84), IL-2 (85) were also tried to strengthen the antibody response. Treatment with recombinant human erythropoietin was associated with increased antibody titers after hepatitis B vaccination in dialysis patients (86). Treatment with a vitamin $D$ receptor activator had no influence on the antiHBs development (41).

\subsection{Future Directions}

Genetic investigation could help in the development of improved hepatitis B vaccines and may eventually reduce the proportion of vaccine failures (87). Positive response to vaccines was shown to be associated with increased interferon (IFN)-gamma production $(88,89)$. As IL-18 is involved in IFN-gamma production (90-92), it was used to modulate DNA vaccines against $\operatorname{HBV}(89,93$, 94). Channarong et al. (93) have constructed a recombinant plasmid carrying gene encoding HBsAg linked to DNA segment encoding full-length murine IL-18. All vaccinated mice revealed a significant serum anti-HBsAg IgG

\begin{tabular}{|c|c|c|c|}
\hline & Description of Renal Function & SR, \% & Main Results \\
\hline $1988(43)$ & PCR: mean 4.5 (range $2.0-9.8$ ) mg/dL & $42-81$ & $\begin{array}{l}\text { A higher SR for plasma-derived than for recombinant } \\
\text { vaccine }\end{array}$ \\
\hline $1994(51)$ & $\begin{array}{l}\text { GFR: } 25.3 \pm 12.6 \mathrm{~mL} / \mathrm{min} \text { for pre-S2/S vaccine } \\
\text { and GFR: } 24.4 \pm 11.1 \mathrm{~mL} / \mathrm{min} \text { for plasma- } \\
\text { derived vaccine }\end{array}$ & $76-94$ & $\begin{array}{l}\text { A higher SR with anti-HBs titer } \geq 2 \mathrm{IU} / \mathrm{L} \text { was for pre-S2/S } \\
\text { vaccine than for plasma-derived vaccine }\end{array}$ \\
\hline $1999(44)$ & $\begin{array}{l}\text { PCR: } 1.5-3.0 \mathrm{mg} / \mathrm{dL} \text { Pcr: } 3.0-6.0 \mathrm{mg} / \mathrm{dL} \text { PCR: } \\
>6.0 \mathrm{mg} / \mathrm{dL}\end{array}$ & $\begin{array}{l}87.5-10066.6- \\
7735.7-36.6\end{array}$ & $\begin{array}{l}\text { SR was negatively dependent on PCR and positively on } \\
\text { vaccine dose }\end{array}$ \\
\hline $2002(46)$ & PCR: $>400 \mu \mathrm{mol} / \mathrm{L}$ & 68 & SR was similar in pre-dialysis, HD and PD patients \\
\hline $2003(45)$ & $\begin{array}{l}\text { GFR: median } 20 \text { (interquartile range } 14 \text { to } \\
\text { 20) } \mathrm{mL} / \mathrm{min}\end{array}$ & 82 & The higher GFR the higher SR \\
\hline $2003(47)$ & PCR: $5.6 \pm 0.4 \mathrm{mg} / \mathrm{dL}$ & $85.7-89.5$ & $\begin{array}{l}\text { ID vaccination at a lower dose provided comparable SR } \\
\text { like IM route at double the standard dose }\end{array}$ \\
\hline $2005(61)$ & PCR: $200-600 \mu \mathrm{mol} / \mathrm{L}$ & $57-81$ & SR was dependent neither on GFR nor vaccine dose \\
\hline $2011(14)$ & GFR: $27.7 \pm 14.7 \mathrm{~mL} / \mathrm{min} / 1.73 \mathrm{~m}^{2}$ & 78 & $\begin{array}{l}\text { SR was not dependent on GFR, but anti-HBs titer } \\
\text { positively correlated with GFR }\end{array}$ \\
\hline $2012(41)$ & $\begin{array}{l}\text { CKD stage } 3 \text { - 5D GFR: } 22.8 \pm 8.5 \mathrm{~mL} / \mathrm{min} / 1.73 \\
\mathrm{~m}^{2} \text { in non-dialysis patients }\end{array}$ & $\begin{array}{l}57 \text { (in the } \\
\text { entire group) }\end{array}$ & $\begin{array}{l}\text { SR and anti-HBs titer were positively dependent on } \\
\text { vitamin D levels Dialysis/pre-dialysis status was not a } \\
\text { predictor of SR }\end{array}$ \\
\hline $2012(50)$ & CKD stage $3-4$ & $77-92$ & $\begin{array}{l}\text { No differences in SR dependent on vaccination } \\
\text { schedule }(4 \times 40 \mu \mathrm{g} \text { vs. } 3 \times 20 \mu \mathrm{g})\end{array}$ \\
\hline
\end{tabular}

Abbreviations: anti-HBs: antibodies to surface antigen of hepatitis B virus, CKD: chronic kidney disease, GFR: glomerular filtration rate, HD: hemodialysis, ID: intradermal, IM: intramuscular, Pcr: plasma creatinine concentration, PD: peritoneal dialysis, SR: seroconversion rate. 
response after two intramuscular injections of the vaccines as compared to the level of mice vaccinated without DNA segment encoding IL-18. It is conceivable that in the near future all people worldwide will be vaccinated on the mandatory basis. The World Health Organization has recommended that hepatitis B vaccination should be included in a worldwide routine immunization for all children. Cost-benefit analyses have strongly supported the introduction of universal vaccination against HBV to newborns $(95,96)$. Results of children's vaccination, which were evaluated in the six-year outcome of the program, showed neither new cases of HBsAg de novo nor seroconversion to anti-HBc positivity (54).

\section{Conclusions}

There are several reasons for hepatitis B vaccination of CKD patients in early stages of their chronic disease:

1) Less severe immune abnormalities in early CKD stages give a chance for higher seroconversion rates,

2) Immunization of RRT dependent patients is less satisfactory than that shown in non-dialyzed CKD patients,

3) An immune response to vaccination is stronger in early CKD stages,

4) If patients are vaccinated early, pre-dialysis HBV infection may be avoided,

5) A response to booster doses in patients responding for the primary vaccination in early CKD stages is usually maintained during RRT.

Results of hepatitis B vaccination in non-dialyzed CKD patients are summarized in Table 1 . The best results of vaccination are shown up to CKD stage 3 - 4. In CKD stage 5 results are often not significantly different from those attained in CKD stage 5D. A vaccination schedule is not established for non-dialyzed CKD patients, but more advanced schedules should be taken into account, especially in later CKD stages. A full success in prevention of HBV transmission and spread is obtained when an implementation of prophylactic education and appropriate infection control procedures are applied together with vaccination.

\section{Acknowledgments}

None declared.

\section{Financial Disclosure}

None declared.

\section{Funding/Support}

None declared.

\section{References}

1. Recommendation of the Immunization Practices Advisory Committee (ACIP). Inactivated hepatitis B virus vaccine. MMWR Morb Mortal Wkly Rep.1982;31(24):317-22, 27-8.

2. Report of the Advisory Group in Hepatitis, Hepatitis B vaccine, guidance on use; 1982; London: Department of health and social security.

3. Jibani MM, Heptonstall J, Walker AM, Bloodworth LO, Howard AJ. Hepatitis B immunization in UK renal units: failure to put policy into practice. Nephrol Dial Transplant. 1994;9(12):1765-8.

4. Cendoroglo Neto M, Draibe SA, Silva AE, Ferraz ML, Granato C, Pereira CA, et al. Incidence of and risk factors for hepatitis B virus and hepatitis $C$ virus infection among haemodialysis and CAPD patients: evidence for environmental transmission. Nephrol Dial Transplant. 1995;10(2):240-6.

5. Miller ER, Alter MJ, Tokars JI. Protective effect of hepatitis B vaccine in chronic hemodialysis patients. Am J Kidney Dis. 1999;33(2):356-60.

6. Finelli L, Miller JT, Tokars JI, Alter MJ, Arduino MJ. National surveillance of dialysis-associated diseases in the United States, 2002. Semin Dial. 2005;18(1):52-61.

7. Grzegorzewska AE, Kaczmarek-Leki V, Młot-Michalska M, Niepolski L. Seroconversion rate to positivity for antibodies against core antigen of hepatitis B virus and duration of renal replacement therapy. Nephrol Dial Transplant. 2011;26(3):970-6.

8. Johnson DW, Dent H, Yao Q, Tranaeus A, Huang C-C, Han D-S, et al. Frequencies of hepatitis B and $C$ infections among haemodialysis and peritoneal dialysis patients in Asia-Pacific countries: analysis of registry data. Nephrology Dialysis Transplantation. 2009;24(5):1598-603.

9. Thanachartwet $V$, Phumratanaprapin $W$, Desakorn V, Sahassananda D, Wattanagoon Y, Chaiprasert A, et al. Viral hepatitis infections among dialysis patients: Thailand registry report. Nephrology (Carlton). 2007;12(4):399-405.

10. Shakhgil'dian IV, Khukhlovich PA, Savin EA, Kuzin SN, Anan'ev VA, Sergeeva NA, et al. [Risk of infection with hepatitis B and C viruses of medical workers, patients in the hemodialysis ward, and vaccine prophylaxis of hepatitis B infection in these populations]. Vopr Virusol. 1994;39(5):226-9.

11. European Best Practice Guidelines.Prevention and management of HBV, HCV and HIV in HD patients. Nephrol Dial Transplant. 2002;17:72-87.

12. Fabrizi F, Dixit V, Bunnapradist S, Martin P. Meta-analysis: the dialysis mode and immunological response to hepatitis $B$ virus vaccine in dialysis population. Aliment Pharmacol Ther. 2006;23(8):1105-12.

13. Grzegorzewska AE, Kurzawska-Firlej D, Swiderski A, de MezerDambek M, Frankiewicz D, Zaremba-Drobnik D, et al. [Infections with hepatitis B virus in hemodialysis units of Wielkopolska]. Przegl Epidemiol. 2008;62(1):29-37.

14. Hashemi B, Mahdavi-Mazdeh M, Abbasi M, Hosseini-Moghaddam SM, Zinat NH, Ahmadi F. Efficacy of HBV vaccination in various stages of chronic kidney disease: is earlier better? Hepat Mon. 2011;11(10):816-20.

15. Pol S, Legendre C, Mattlinger B, Berthelot P, Kreis H. Genetic basis of nonresponse to hepatitis B vaccine in hemodialyzed patients. J Hepatol. 1990;11(3):385-7.

16. Roznovsky L, Tvrdik J, Kabieszova L, Petrousova L, Orsagova I, Hozakova L, et al. [Vaccination against hepatitis B in patients with chronic renal failure-twenty years follow-up]. Vnitr Lek. 2011;57(10):808-14.

17. Sali S, Alavian SM, Hajarizadeh B. Effect of levamisole supplementation on hepatitis B virus vaccination response in hemodialysis patients. Nephrology (Carlton). 2008;13(5):376-9.

18. Tsouchnikas I, Dounousi E, Xanthopoulou K, Papakonstantinou S, Thomoglou V, Tsakiris D. Loss of hepatitis B immunity in hemodialysis patients acquired either naturally or after vaccination. Clin Nephrol. 2007;68(4):228-34.

19. Morbidity and Mortality Weekly Report. Recommendations for preventing transmission of infections among chronic hemodialysis patients. U.S. Department of Health and Human Services. Centers for Disease Control and Prevention. 2001;50:RR-5.

20. Grzegorzewska AE, Kurzawska-Firlej D, Ratajewski W, Frankiewicz D, Niepolski L, Kaczmarek A. Antibodies to core antigen of hepatitis B virus in patients on renal replacement therapy: association with demographic, clinical and laboratory data. Nephron Clin Pract. 2010;114(3):c194-203. 
21. Sengar DP, McLeish WA, Sutherland M, Couture RA, Rashid A. Hepatitis B antigen (HBAg) infection in a hemodialysis unit. I. HL-A8 and immune response to HBAg. Can Med Assoc J. 1975;112(8):968, 71

22. Sengar DP, Rashid A, Jindal SL, Christie CJ. HLA antigens in HBsAg infection. Vox Sang. 1979;36(6):353-5.

23. Hashimoto E, Obata H, Nakanishi T, Kaneko A, Kurihara T, Tomimatsu T, et al. HLA antigens and anti-HBs response to hepatitis B vaccine. Acta Hepatol Jpn. 1985;26.

24. Watanabe H, Matsushita S, Kamikawaji N, Hirayama K, Okumura M, Sasazuki T. Immune suppression gene on HLA-Bw54-DR4DRw53 haplotype controls nonresponsiveness in humans to hepatitis B surface antigen via CD8+ suppressor T cells. Hum Immunol. 1988;22(1):9-17.

25. Alper CA, Kruskall MS, Marcus-Bagley D, Craven DE, Katz AJ, Brink SJ, et al. Genetic prediction of nonresponse to hepatitis B vaccine. N Engl J Med.1989;321(11):708-12.

26. Walker M, Szumuness W, Stevens C, Rubinstein P. Genetics of anti-HBs responsiveness. I. HLA-DR7 and non-responsiveness to hepatitis vaccination Transfusion. 1981;21.

27. Hatae K, Kimura A, Okubo R, Watanabe H, Erlich HA, Ueda K, et al. Genetic control of nonresponsiveness to hepatitis B virus vaccine by an extended HLA haplotype. Eur J Immunol. 1992;22(7):1899905.

28. Hohler T, Meyer CU, Notghi A, Stradmann-Bellinghausen B, Schneider PM, Starke R, et al. The influence of major histocom patibility complex class II genes and T-cell Vbeta repertoire on response to immunization with HBsAg. Hum Immunol. 1998;59(4):212-8.

29. Girndt M, Sester U, Sester M, Deman E, Ulrich C, Kaul H, et al. The interleukin-10 promoter genotype determines clinical immune function in hemodialysis patients. Kidney Int. 2001;60(6):2385-91.

30. Grzegorzewska AE, Wobszal P, Jagodzinski PP. Interleukin-18 promoter polymorphism and development of antibodies to surface antigen of hepatitis B virus in hemodialysis patients. Kidney Blood Press Res. 2012;35(1):1-8.

31. Grzegorzewska AE, Wobszal PM, Mostowska A, Jagodzinski PP. Antibodies to hepatitis B virus surface antigen and interleukin 12 and interleukin 18 gene polymorphisms in hemodialysis patients. BMC Nephrol. 2012;13:75.

32. Fabrizi F, Martin P, Dixit V, Bunnapradist S, Dulai G. Meta-analysis: the effect of age on immunological response to hepatitis $\mathrm{B}$ vaccine in end-stage renal disease. Aliment Pharmacol Ther. 2004;20(10):1053-62.

33. Jadoul M, Goubau P. Is anti-hepatitis B virus (HBV) immunization successful in elderly hemodialysis (HD) patients? Clin Nephrol. 2002;58(4):301-4.

34. Shatat HZ, Kotkat AM, Farghaly AG. Immune response to hepatitis B vaccine in haemodialysis patients. J Egypt Public Health Assoc. 2000;75(3-4):257-75.

35. Stevens C, Alter H, Taylor P, Zang E, Harley E, Szmuness W. The Dialysis Vaccine Trial Study Group: Hepatitis B vaccine in patients receiving hemodialysis. $N$ Engl J Med.1984;311:496-501.

36. Brown CM, Donlon S, O'Kelly P, Casey AM, Collier C, Conlon PJ, et al. A prospective study of hepatitis B vaccination - a comparison of responders versus nonresponders. Ren Fail. 2011;33(3):276-9.

37. Fernandez E, Betriu MA, Gomez R, Montoliu J. Response to the hepatitis $B$ virus vaccine in haemodialysis patients: influence of malnutrition and its importance as a risk factor for morbidity and mortality. Nephrol Dial Transplant. 1996;11(8):1559-63.

38. Navarro JF, Teruel JL, Mateos ML, Marcen R, Ortuno J. Antibody level after hepatitis B vaccination in hemodialysis patients: influence of hepatitis C virus infection. Am J Nephrol.1996;16(2):95-7.

39. Ahuja TS, Kumar S, Mansoury H, Rodriguez H, Kuo YF. Hepatitis B vaccination in human immunodeficiency virus-infected adults receiving hemodialysis. Kidney Int. 2005;67(3):1136-41.

40. Alavian SM, Tabatabaei SV. The effect of diabetes mellitus on immunological response to hepatitis B virus vaccine in individuals with chronic kidney disease: A meta-analysis of current literature. Vaccine. 2010;28(22):3773-7.

41. Zitt E, Sprenger-Mahr H, Knoll F, Neyer U, Lhotta K. Vitamin D deficiency is associated with poor response to active hepatitis $B$ immunisation in patients with chronic kidney disease. Vaccine. 2012;30(5):931-5.

42. Contin C, Pitard V, Delmas Y, Pelletier N, Defrance T, Moreau JF, et al. Potential role of soluble CD40 in the humoral immune response impairment of uraemic patients. Immunology. 2003;110(1):131-40.

43. Seaworth B, Drucker J, Starling J, Drucker R, Stevens C, Hamilton J. Hepatitis B vaccines in patients with chronic renal failure before dialysis. J Infect Dis. 1988;157(2):332-7.

44. Agarwal SK, Irshad M, Dash SC. Comparison of two schedules of hepatitis B vaccination in patients with mild, moderate and severe renal failure. J Assoc Physicians India. 1999;47(2):183-5.

45. DaRoza G, Loewen A, Djurdjev O, Love J, Kempston C, Burnett S, et al. Stage of chronic kidney disease predicts seroconversion after hepatitis B immunization: earlier is better. Am J Kidney Dis. 2003;42(6):1184-92.

46. Bel'eed K, Wright M, Eadington D, Farr M, Sellars L. Vaccination against hepatitis $B$ infection in patients with end stage renal disease. Postgrad Med J. 2002;78(923):538-40.

47. Pippi F, Bracciale L, Stolzuoli L, Giaccherini R, Montomoli E, Gentile $C$, et al. Serological response to hepatitis B virus vaccine in HIV-infected children in Tanzania. HIV Med. 2008;9(7):519-25.

48. Joint Committee on Vaccination, Immunization, Great Britain. Dept. of Health. Immunisation against infectious disease. London: H.M.S.O.; 1988

49. Great Britain. Dept. of Health. Immunisation Against Infectious Disease. London: H.M. Stationery Office; 1990.

50. Ahmadi F, Ramezani M, Razeghi E, Ranjbarnovin N, Khazaeipour Z. A randomized controlled trial of two schedules of hepatitis B vaccination in predialysed chronic renal failure patients. Hepat Mon. 2012;12(5):344-8.

51. Jungers P, Chauveau P, Courouce AM, Abbassi A, Devillier P, Marie FN, et al. [Recombinant vaccine and extracting vaccine against hepatitis B in patients with kidney insufficiency: comparative immunogenicity]. Presse Med.1994;23(6):277-80.

52. Loza Munarriz C, Depaz Dolores M, Suarez Jara M, Loza Munarriz R, Valenzuela Cordova R, Bravo Tejada J, et al. [Rate of serological markers of hepatitis B and C viruses in first-time users of the hemodialysis program at Hospital Nacional Cayetano Heredia (HNCH)]. Rev Gastroenterol Peru. 2005;25(4):320-7.

53. McMahon BJ, Bruden DL, Petersen KM, Bulkow LR, Parkinson AJ, Nainan O, et al. Antibody levels and protection after hepatitis B vaccination: results of a 15 -year follow-up. Ann Intern Med. 2005;142(5):333-41.

54. Avazova D, Kurbanov F, Tanaka Y, Sugiyama M, Radchenko I, Ruziev D, et al. Hepatitis B virus transmission pattern and vaccination efficiency in Uzbekistan. J Med Virol. 2008;80(2):217-24.

55. West DJ, Calandra GB. Vaccine induced immunologic memory for hepatitis B surface antigen: implications for policy on booster vaccination. Vaccine. 1996;14(11):1019-27.

56. Lok AS, McMahon BJ. Chronic hepatitis B: update 2009. Hepatology. 2009;50(3):661-2.

57. Dukes CS, Street AC, Starling JF, Hamilton JD. Hepatitis B vaccination and booster in predialysis patients: a 4-year analysis. Vaccine. 1993;11(12):1229-32.

58. Lefebure AF, Verpooten GA, Couttenye MM, De Broe ME. Immunogenicity of a recombinant DNA hepatitis $B$ vaccine in renal transplant patients. Vaccine. 1993;11(4):397-9.

59. Lindsay KL, Herbert DA, Gitnick GL. Hepatitis B vaccine: low postvaccination immunity in hospital personnel given gluteal injections. Hepatology. 1985;5(6):1088-90.

60. Ukena T, Esber H, Bessette R, Parks T, Crocker B, Shaw FE, Jr. Site of injection and response to hepatitis B vaccine. $N$ Engl J Med. 1985;313(9):579-80.

61. McNulty CA, Bowen JK, Williams AJ. Hepatitis B vaccination in predialysis chronic renal failure patients a comparison of two vaccination schedules. Vaccine. 2005;23(32):4142-7.

62. Good Practice Guidelines for Renal Dialysis/Transplantation Units Prevention and Control of Blood-borne Virus Infection. London: Department of Health; 2002.

63. Landreneau MD, DeVault GA, Rohr MA, Kilpatrick JS, King JW, Rhynes VK, et al. Transmission of hepatitis B by renal transplan- 
tation despite active immunization with hepatitis B vaccine. Clin Transplant. 1988;2:265-9

64. Lombardi M, Pizzarelli F, Righi M, Cerrai T, Dattolo P, Nigrelli S, et al. Hepatitis $B$ vaccination in dialysis patients and nutritional status. Nephron. 1992;61(3):266-8.

65. Su WJ, Ho MC, Ni YH, Chen HL, Hu RH, Wu YM, et al. High-titer antibody to hepatitis B surface antigen before liver transplantation can prevent de novo hepatitis B infection. J Pediatr Gastroenterol Nutr. 2009;48(2):203-8.

66. Fabrizi F, Martin P. Hepatitis B virus infection in dialysis patients. Am J Nephrol. 2000;20:1-11.

67. Trepo CG, Prince AM. Absence of complete homologous immunity in hepatitis B infection after massive exposure. Ann Intern Med.1976;85(4):427-30.

68. Hoofnagle JH, Gerety RJ, Smallwood LA, Barker LF. Subtyping of hepatitis B surface antigen and antibody by radioimmunoassay. Gastroenterology. 1977;72(2):290-6.

69. Koziol DE, Alter HJ, Kirchner JP, Holland PV. The development of HBsAg-positive hepatitis despite the previous existence of antibody to HBsAg. J Immunol. 1976;117(6):2260-2.

70. Chabaud M, Depril N, Le Cann P, Leboulleux D, Nandi R, Coll-Seck $A M$, et al. Detection of hepatitis B virus DNA by polymerase chain reaction in vaccinated and non-vaccinated Senegalese children. Arch Virol Suppl.1993;8:123-31.

71. Waters JA, Kennedy M, Voet P, Hauser P, Petre J, Carman W, et al. Loss of the common "A" determinant of hepatitis B surface antigen by a vaccine-induced escape mutant. J Clin Invest. 1992;90(6):2543-7.

72. Fabrizi F, Dixit V, Magnini M, Elli A, Martin P. Meta-analysis: intradermal vs. intramuscular vaccination against hepatitis $B$ virus in patients with chronic kidney disease. Aliment Pharmacol Ther. 2006;24(3):497-506.

73. Marangi AL, Giordano R, Montanaro A, De Padova F, Schiavone MG, Dongiovanni G, et al. Hepatitis B virus infection in chronic uremia: long-term follow-up of a two-step integrated protocol of vaccination. Am J Kidney Dis. 1994;23(4):537-42.

74. Somboonsilp W, Eiam-Ong S, Tungsanga K, Tirawatanapong T Immune response of intradermal hepatitis $B$ vaccination at lower dose versus intramuscular vaccination at double standard dose in predialytic chronic renal failure patients. J Med Assoc Thai. 2003;86(12):1122-7.

75. Milich DR, McLachlan A, Chisari FV, Kent SB, Thorton GB. Immune response to the pre- $\mathrm{S}(1)$ region of the hepatitis $\mathrm{B}$ surface antigen (HBsAg): a pre-S(1)-specific $\mathrm{T}$ cell response can bypass nonresponsiveness to the pre-S(2) and S regions of HBsAg. J Immunol. 1986;137(1):315-22.

76. Gerlich WH, Deepen R, Heermann KH, Krone B, Lu XY, Seifer M, et al. Protective potential of hepatitis B virus antigens other than the S gene protein. Vaccine. 1990;8 Suppl:S63-8; discussion S7980.

77. Polito P, Di Lullo L, Iannacci GR, Cecilia A, Galderisi C, Gorini A. [Seroconversion and immune response after anti-HBV vaccination in patients on chronic hemodialysis: comparison of two vaccines]. G Ital Nefrol. 2011;28(5):525-30.

78. Surquin M, Tielemans C, Nortier J, Jadoul M, Peeters P, Ryba M, et al. Anti-HBs antibody persistence following primary vaccination with an investigational ASO2(v)-adjuvanted hepatitis B vaccine in patients with renal insufficiency. Hum Vaccin. 2011;7(9):913-8.

79. Tielemans CL, Vlasak J, Kosa D, Billiouw JM, Verpooten GA, Mezei I, et al. Immunogenicity and safety of an investigational ASO2(v)adjuvanted hepatitis $B$ vaccine in patients with renal insufficiency who failed to respond or to maintain antibody levels after prior vaccination: results of two open, randomized, comparative trials. Vaccine. 2011;29(6):1159-66.

80. Fabrizi F, Dixit V, Messa P, Martin P. Hepatitis B virus vaccine in chronic kidney disease: improved immunogenicity by adjuvants? A meta-analysis of randomized trials. Vaccine. 2012;30(13):2295-300.

81. Duranti E, Duranti D. Polymethylmethacrylate strengthens antibody response in hemodialysis patients not responding to hepatitis B vaccine: preliminary data. Minerva Med. 2011;102(6):469-74.

82. Brodersen HP, Holtkamp W, Larbig D, Beckers B, Thiery J, Lautenschlager J, et al. Zinc supplementation and hepatitis B vaccination in chronic haemodialysis patients: a multicentre study. Nephrol Dial Transplant. 1995;10(9):1780.

83. Donati D, Gastaldi L. Controlled trial of thymopentin in hemodialysis patients who fail to respond to hepatitis B vaccination. Nephron. 1988;50(2):133-6.

84. Verkade MA, van de Wetering J, Klepper M, Vaessen LM, Weimar W, Betjes MG. Peripheral blood dendritic cells and GM-CSF as an adjuvant for hepatitis $B$ vaccination in hemodialysis patients. Kidney Int. 2004;66(2):614-21.

85. Jungers P, Devillier P, Salomon H, Cerisier JE, Courouce AM. Randomised placebo-controlled trial of recombinant interleukin-2 in chronic uraemic patients who are non-responders to hepatitis B vaccine. Lancet. 1994;344(8926):856-7.

86. Sennesael JJ, Van der Niepen P, Verbeelen DL. Treatment with recombinant human erythropoietin increases antibody titers after hepatitis $\mathrm{B}$ vaccination in dialysis patients. Kidney Int 1991;40(1):121-8.

87. Hennig BJ, Fielding K, Broxholme J, Diatta M, Mendy M, Moore $\mathrm{C}$, et al. Host genetic factors and vaccine-induced immunity to hepatitis B virus infection. PLoS One. 2008;3(3):e1898.

88. Petrescu L, Stancu S, Tardei G, Santimbrean C, Penescu M, Mircescu G. Tuberculin skin test, interferon-gamma assay, and T cells subpopulations in hemodialysis patients. J Ren Nutr. 2010;20(5 Suppl):S109-17.

89. Tang LL, Liu KZ. Recent advances in DNA vaccine of hepatitis virus. Hepatobiliary Pancreat Dis Int. 2002;1(2):228-31.

90. Kim JJ, Nottingham LK, Tsai A, Lee DJ, Maguire HC, Oh J, et al. Antigen-specific humoral and cellular immune responses can be modulated in rhesus macaques through the use of IFN-gamma, IL-12, or IL-18 gene adjuvants. J Med Primatol. 1999;28(4-5):214-23.

91. Tominaga K, Yoshimoto T, Torigoe K, Kurimoto M, Matsui K, Hada T, et al. IL-12 synergizes with IL-18 or IL-1beta for IFN-gamma production from human T cells. Int Immunol. 2000;12(2):151-60.

92. Yoshimoto T, Takeda K, Tanaka T, Ohkusu K, Kashiwamura S, Okamura $\mathrm{H}$, et al. IL-12 up-regulates IL-18 receptor expression on T cells, Th1 cells, and B cells: synergism with IL-18 for IFN-gamma production.JImmunol.1998;161(7):3400-7.

93. Channarong S, Mitrevej A, Sinchaipanid N, Usuwantim K, Kulkeaw K, Chaicumpa W. Cloning, protein expression and immunogenicity of HBs-murine IL-18 fusion DNA vaccine. Asian Pac J Allergy Immunol. 2007;25(4):233-42.

94. Chen JZ, Zhu HH, Liu KZ, Chen Z. Enhancing cellular immune response to HBV M DNA vaccine in mice by codelivery of interleukin-18 recombinant. J Zhejiang Univ Sci. 2004;5(4):467-71.

95. Arevalo JA, Washington AE. Cost-effectiveness of prenatal screening and immunization for hepatitis B virus. JAMA: the journal of the American Medical Association. 1988;259(3):365-9.

96. Ginsberg GM, Shouval D. Cost-benefit analysis of a nationwide neonatal inoculation programme against hepatitis B in an area of intermediate endemicity. J Epidemiol Community Health. 1992;46(6):587-94. 